\title{
Sepětí věcné a krásné literatury: Leskov, pravoslaví a publicistika
}

\begin{abstract}
ŁUKASZEWICZ, М.: «Я не враг церкви, а ее друг... и уверенный православный...» Церковная проблематика в публицистике Николая Лескова. Warszawa: Wydział Lingwistyki Stosowanej Uniwersytetu Warszawskiego, Wydawnictwo Uniwersytetu Warszawskiego, 2019. ISBN 978-83-235-4137-o (druk), 978-83-235-4145-5 (pdf online).
\end{abstract}

Když jsem na hraně 70. a 80. let minulého století poprvé četl asi nejobsáhlejší a nejreprezentativnější, patrně dosud nepřekonanou knihu o Leskovovi, amerického rusisty Hugh Mac Leana ${ }^{1}$ ohromila mě informace o tom, jak spisovatel začal psát a co vlastně byla jeho literární prvotina jako emblém jeho novinářské kariéry, v němž se jako v kapce vody zrcadlí i celá jeho osobnost a dílo, totiž spojení víry a pragmatismu: glosa o tom, za jakou cenu se v Kyjevě (kde mladý Leskov pobýval na pozvání svého strýce, profesora místní univerzity Alfer’jeva) se prodávají překlady evangelií. Jinak řečeno: nelze tohoto autora, ale jistě i řadu jiných vysvětlit jen na základě jejich uměleckých děl; je zde - pokud takoví byli - i publicistika a další jejich výtvory, které tak či onak s krásnou literaturou souvisejí. U Leskova je to problematika náboženství, která má s pragmatikou společná místa, nebot̉ Leskov byl v otázkách víry ukotvený, nebot’ se hlásil, jak autorka v titulku citátem z něho samého zdůrazňuje, k pravoslaví a byl věrným synem církve, i když měl zcela pochopitelně pochopení pro jiné denominace (jak je ostatně typické pro pravoslaví jako takové, v minulosti mnohem tolerantnější $\mathrm{k}$ jiným vírám a církvím než např. katolická církev), viděl svět šíře, než se myslelo právě o něm jako uzavřeně ruském, takřka nepřeložitelném autorovi. Na to autorka upozorňuje ve své rozsáhlé publikaci, která čítá 541 stran velkého formátu se spoustou dokumentace, citátů, odkazů na primární a sekundární literaturu a nespočet analýz. Nelze jí vytýkat, že na některé materiály zapomněla nebo je nepovažovala za natolik důležité; uvádět všechno se v případě tohoto dříve outsidera ruské literatury, dnes módního autora, ani nedá.

V podstatě jde o práci sice primárně literárněvědnou, nebot’ se zabývá texty, i když publicistickými, a upozorňuje na spojitosti s uměleckou tvorbou autora nebo je alespoň aluzívně evokuje, ale jinak je to kniha multidisciplinární pohybující se na hranici sociologie, sociální psychologie, religionistiky, teologie a církevních dějin. Velmi podrobně se tu typologizuje Leskovova publikační činnost v širokém kontextu

1 MAC LEAN, H.: Nikolai Leskov: The Man and His Art. Harvard: Harvard University Press, 1977. 
dobové ruské aktivity a zejména sféra víry a církví v liberální, volnomyšlenkářské Evropě 19. století, hlavně jeho druhé poloviny. Aniž se o tom autorka zmiňuje, je zřejmé, že ruská literatura jako celek nebo přímo Rusko byly pro Evropu šokem právě svým sklonem $\mathrm{k}$ viŕre, $\mathrm{k}$ pravoslaví, východnímu křestanství a církvím uprostřed dominantního pozitivismu s projevy otevřeného zájmu o jiné denominace: Leskov psal o quakerech, ale také o světových náboženstvích mimo křest’anství a není divu, nebot Rusko bylo a dodnes je př́mo laboratoří věr a církví a Leskov sám zkoumal z vládního pověření starověrce/raskolniky v rusko-německo-švédské Baltii, ale také projevil sympatie $\mathrm{k}$ tatarským muslimům. Leskov si byl současně vědom toho, že pravoslavná církev je nemocná a tím se př́liš neliší od jiných křestanských církví v Evropě a asi ani od jiných. Jednak je tu vztah k světské moci (2. kap.), jednak je zde vlastní hierarchická struktura církve a její rízení a vztah vysokých představitelů a řadového kněžstva (3. kap.); dále duchovní/náboženské školství a vzdělávání, jak se reflektuje $\mathrm{v}$ ruské publicistice a a beletrii (4. kap.), šíření víry a jejích ustanovení a role farního/parochiálního duchovenstva (5. kap.); „parádni“ kapitola se pochopitelně týká klášterů a mnichů v měnící se společnosti v době reforem (v Rusku od 50.-60. let 19. století).

Ukazuje se, že Leskov se ve své publicistice, ale i ve svých uměleckých dílech dotkl prakticky všech podstatných otázek souvisejících s vírou, náboženstvím a církvemi, zejména s pravoslavnou. Jeho stanoviska byla přitom zasažena jednak jeho obvyklou, až protestantskou (jak o tom kdysi psal James Muckle ${ }^{2}$ ) racionalitou, střídmostí, stř́zlivostí a věcností, jednak tím, že z vlastní zkušenosti poznal a prožil různé denominace a náboženská prostředí a hlavně nezapomeňme, že jeho první cesta do Evropy střední a západní (1862-1863) po tzv. skandálu s jeho statí o petrohradských požárech (stal se tak nepřítelem radikálních revolucionářů, kteří však ovládali veškerý vlivný tisk, ale $\mathrm{k}$ jeho „požární stati“ se negativně vyjádřil i jinak liberální car Alexandr II., nebot Leskovova kritika se týkala také nečinnosti úřadů). Vedla pro Rusy tehdy nepatřičně nikoli přes Berlín do Paříže, ale přes ruskou Ukrajinu, rakouskou Halič do Praha a Pařiže (v českých zemích byl třikrát $\left.{ }^{3}\right)$ : Leskov se zde setkal

2 MUCKLE, J.: Nikolai Leskov and "the Spirit of Protestantism". Birmingham 1978.

3 Jak jsme vícekrát psali, jeho postoj k Čechám a Čechům byl značně ambivalentní. Do Prahy přijiždí na podzim 1862, jako novinář (Северная пчела) navštěvuje redakce Národních listů a Osvěty, setkává se mj. s Ferdinandem Schulzem a Emanuelem Tonnerem (1829-190o), který ho prý začal učit česky. Z proslulého almanachu Lada-Nióla (1855) si k překladu vybral povídku Marie od M. Brodského (pseudonym K. V. Friče, tehdy politicky nevhodného) a literární pohádku B. Němcové $O d v a n a ́ c t i$ měsičkách a bylo odhaleno, že je i autorem glosy o „Božině Němcové“; v Paříži se setkává s polskými a českými emigranty, včetně J. V. Friče. Při dalších cestách byl návštěvníkem Mariánských Lázní, kde zanechal zápis v lázeňské knize; při třetí cestě mu v Praze ukradli všechny doklady a peníze. Čechů se týká naivní povídka Alexandrit; v korespondenci nazývá češtinu „птичий язык“ а jinde dokonce zakazuje překládat „мои бессмертные творения“ do češtiny, nebot', jak uvádí, „я очень 
s politickými emigranty, poznal složité náboženské poměry ve střední a západní Evropě, nemluvě o jeho vládním zkoumání baltských starověrců. Ve vztahu pravoslavné církve a světské moci byl spíše skeptický a odmítavý: někdy se v tom bližíi až evropskému pozitivismu, když tvrdí, že církev má především posilovat veřejnou mravnost, aniž by však popíral transcendentní roli víry. Nepřímou verifikací jeho blízkosti různým moderním evropským myšlenkovým proudům může být i vznik podivných, leč logických řetězců: fakt, že T. G. Masaryk miloval Gorkého a pokládal ho za vůdčího ruského spisovatele počínajícího 2o. století navazujícího na ruskou klasiku; Gorkij měl zase rád Leskova a všichni tři byli podivní věrící a měli zvláštní vztah k náboženství a církvím (Masarykovo platónství a křest’anství: „Ježíš, ne Caesar!“, Gorkého bohohledačství a bohostrůjcovství, Leskovovo tíhnutí k hluboce prožité viŕre dotvrzené praktickými skutky - „spravedliví“/ праведники). Samozřejmě toto v knize nenajdeme, zato je zde mnoho materiálů a také rozsáhlá bibliografie k tématu, že ji takto komplexně nezachytili žádní ruští leskovologové, kteří - jak vidno právě z bibliografie - postihli vždy jen nějaké výseky. Duchovní, náboženská a církevní tematika v Leskovově díle publicistickém i beletristickém se dostává do epicentra pozornosti. Naše dvě brněnská leskovovská kolokvia v rámci doktorských škol, která se konala v letech 2017 a 2019 (2018 je vystř́́dalo kolokvium o Dostojevském) tuto tendenci jasně doložila. Zasloužila se o to také sama autorka, která nás do problematiky její tehdy ještě nepublikované monografie vlastně zasvětila ve studii o náboženské tematice $\mathrm{v}$ Leskovově díle ve vztahu $\mathrm{k}$ metodologii. Již zde vytyčila základní metodologické dilema: tradiční, spočívající ve studiu Leskovových prací $\mathrm{s}$ touto tematikou $\mathrm{v}$ kontextu obdobných př́stupů a sociálních problémů druhé poloviny 19. století, a postsekulární, tkvící v moderní obnově vztahu k náboženství a k roli církví a $\mathrm{k}$ viŕe jako takové $\mathrm{v}$ ateizující se společnosti druhé poloviny 19. a celém 2o. století. ${ }^{4}$ Ve druhém brněnském leskovovském svazku z kolokvia o románu v díle N.S. Leskova je zřejmé, že jádrem religiózního tématu u Leskova a jeho pramenem

не люблю этого языка“ (Viz např. naši knihu Proti proudu. Studie o N. S. Leskovovi. Sprint-Print, Brno 1992, s. 12, 53 n.).

4 Viz POSPÍŠIL, I. (ed.): Leskovi vokrug. Konteksty tvorčestva i sostojanije sovremennogo leskovovedenija. Ústav slavistiky Masarykovy univerzity, Brno 2018. Studie Marty Łukaszewicz Issledovanija religioznoj problematiki $v$ tvorčestve Nikolaja Leskova: voprosy metodologii. In: POSPÍŠIL, I. (ed.): Leskov i vokrug. Konteksty tvorčestva i sostojanije sovremennogo leskovovedenija. Brno: Ústav slavistiky Masarykovy univerzity, 2018, s. 105-113. POSPÍŠIL, I.: The Secular, the Sacral, and the Three Stages of the Postsecular in Russian Literature: The Past and the Present. In: SOSNOWSKA, D., DRZEWIECKA, E. (eds): The Experience of Faith in Slavic Cultures and Literatures. in the Context of Postsecular Thought. Warszawa: Wydawnictwo Uniwersytetu Warszawskiego, 2018, s. 178-188. POSPÍŠIL, I.: Politická a akademická objednávka v literární vědě a dvě témata: postsekularismus a ekfráze. In: POSPÍŠIL, I., ZELENKA, M., PAUČOVÁ, L. (eds): Kontexty literární vědy VIII. Brno: Tribun EU, 2018, s. 143-162. POSPÍŠIL, I.: Anticipace postsekularity v první Československé republice jako syntéza a východisko $k$ světovosti české literatury. Slavica Litteraria 2019, č. 2, s. 19-35. 
je Kyjev a pobyt Leskova v tomto městě, jak ve svém př́spěvku zaznamenali Olha Červins'kaja a Roman Dzyk. ${ }^{5}$

Jinak řečeno, studium problematiky církve, víry, náboženských denominací a religiozity na pozadí vývoje teologických koncepcí a společnosti se týká problémů konkrétní, historicky ukotvené doby, nebo jde o studium jevů a názorů, jež už tehdy anticipovaly zejména situaci v druhé polovině 20 . a v první třetině 21 . století, tedy tíhnutí k religióznímu vidění světa, ale jinému než ve středověku nebo ještě v 19. století, jak o tom ostatně ve své knize Nový středověk předvídavě psal Nikolaj Berdajev ${ }^{6}$. Téma má tedy své přesahy a mírí k současnosti a budoucnosti, byt se zdá zavaleno materiálem striktně vymezené doby.

To, co je problematické, je především menší míra zření k leskovovské produkci románské, někdy i germánské, ale hlavně obecně středoevropské. Některé jazyky se prostě mezi rusisty nečtou, i když jsou až nepř́ijemně blízké - nebo právě proto? jazyku autorů a zdá se mi, že ani Hugh Mac Lean píšící americkou angličtinou není exploatován, tř̌eba polemicky, adekvátně. Chybí mi tu, pokud dobře čtu a pozorně se dívám, Ital Danilo Cavaion s jeho „kritickou eseji “" ${ }^{\text {“7 }}$ v níž upozornil na historicitu Leskovových románových kronik a na jeho vztah k „starým časům“, což se náboženství týká v první řadě, nebo další autoři, kteři se tématu dotkli také poměrně výrazně nebo i marginálně. Poměrně málo je tu využito vztahu mezi publicistikou a krásným písemnictvím ve smyslu poetologické návaznosti nebo vzájemného propojení, tedy recipročního morfologického působení obou sfér, v podstatě toho, jak se Leskovovi podařilo či nepodařilo prretavit věcnou literaturu do beletrie, jako se to vcelku dařilo např́klad Dostojevskému nebo později Karlu Čapkovi, nebơ také oni byli primárně novináři, autoři deníků, esejů, glos, cestopisů, politických pamfletů s čichem pro aktuálnost, časovost materiálu (Leskov, Dostojevskij i Čapek neváhali čerpat $\mathrm{z}$ „,̌erné kroniky“, z kriminálních př́padů, viz Lady Macbeth, Běsi nebo Povídky z jedné a Povídky z druhé kapsy, Hordubal aj.). Tím se ocitáme na poli, které je podle našeho názoru pro moderní stav světové literatury stěžejní, totiž klíčové postavení literárních artefaktů na hraně věcné a krásné literatury - ty dnes tvoří vrstvu bestsellerů napojených na filmový průmysl, tedy vizualizaci, která nyní literatuře zajištuje komfortnější přežití a možná také ukazuje směrem, jímž se bude její rozhodující část ubírat, zejména próza a román.

$5 \quad$ Viz jejich společnou studii Topografičeskij portret Kijeva: žanrovaja specifika teksta N. Leskova «Pečerskije antiki». In: POSPÍŠIL, I. (ed.): N. S. Leskov i tradicija russkogo romana v mirovom kontekste. Brno: Jan Sojnek. 〈V tisku.

6 BERDJAJEV, N.: Novoje srednevekov'je: razmyšlenije o sud'be Rossii i fevropy. Berlin: Obelisk, 1924. Kniha vyšla také německy, francouzsky i v jiných jazycích, česky jako Nový středověk: úvaha o osudu Ruska a Evropy. Červený Kostelec: Pavel Mervart, 2004. Přel. Jan Kranát.

7 Viz CAVAION, D.: N. S. Leskov. Saggio critico. Firenze: G. C. Sansoni, 1974. 
Nicméně hlavní význam knihy spočívá podle mého soudu v rusistickém multidisciplinárním bádání zasvěceném Leskovovi a ruským problémům 19. století, ovšem přesahujícím $\mathrm{k}$ vlnám celosvětového návratu víry, náboženství a církví do zápasu o podobu člověka a světa. Může to být také přátelská výzva zejména ruským leskovologům, kteří mají $\mathrm{k}$ archivním materiálům a dobovým ruským tiskovinám přece jen nejblíže.

Ivo Pospíšil

\section{Literatura:}

BERDJAJEV, N. A.: Novoje srednevekov'je: razmyšlenije o sud'be Rossii i fevropy. Berlin: Obelisk, 1924.

BERDJAJEV, N. A.: Nový středověk: úvaha o osudu Ruska a Evropy. Červený Kostelec: Pavel Mervart, 2004.

CAVAION, D.: N. S. Leskov. Saggio critico. Firenze: G. C. Sansoni, 1974.

ČERVINSKAJA, O., DZYK, R.: Topografičeskij portret Kijeva: žanrovaja specifika teksta N. Leskova «Pečerskije antiki». In: POSPÍŠIL, I. (ed.): N. S. Leskov i tradicija russkogo romana v mirovom kontekste. Brno: Jan Sojnek. 〈V tisku.〉

ŁUKASZEWICZ, M. Issledovanija religioznoj problematiki v tvorčestve Nikolaja Leskova: voprosy metodologii. In: POSPÍŠIL, I. (ed.): Leskov i vokrug. Konteksty tvorčestva i sostojanije sovremennogo leskovovedenija. Brno: Ústav slavistiky Masarykovy univerzity, 2018, s. 105-113.

ŁUKASZEWICZ, M.: «fa ne vrag cerkvi, a jeje drug... i uverennyj pravoslavnyj...» Cerkovnaja problematika $v$ publicistike Nikolaja Leskova. Warszawa: Wydział Lingwistyki Stosowanej Uniwersytetu Warszawskiego, Wydawnictwo Uniwersytetu Warszawskiego, 2019.

MAC LEAN, H.: Nikolai Leskov: The Man and His Art. Harvard: Harvard University Press, 1977 .

MUCKLE, J.: Nikolai Leskov and "the Spirit of Protestantism". Birmingham 1978.

POSPÍŠIL, I.: Anticipace postsekularity v první Československé republice jako syntéza a východisko $k$ světovosti české literatury. Slavica Litteraria 2019, č. 2, s. 19-35.

POSPÍŠIL, I.: Politická a akademická objednávka v literární vědě a dvě témata: postsekularismus a ekfráze. In: POSPÍŠIL, I., ZELENKA, M., PAUČOVÁ,L. (eds): Kontexty literární vědy VIII. Brno: Tribun EU, 2018, s. 143-162.

POSPÍŠIL, I.: Proti proudu. Studie o N. S. Leskovovi. Sprint-Print, Brno 1992.

POSPÍŠIL, I.: The Secular, the Sacral, and the Three Stages of the Postsecular in Russian Literature: The Past and the Present. In: SOSNOWSKA, D., DRZEWIECKA, E. (eds): 
The Experience of Faith in Slavic Cultures and Literatures. in the Context of Postsecular Thought. Warszawa: Wydawnictwo Uniwersytetu Warszawskiego, 2018, s. $178-188$.

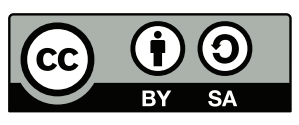

Toto dílo Ize užít v souladu s licenčními podmínkami Creative Commons BY-SA 4.0 International (<https:// creativecommons.org/licenses/by-sa/4.0/legalcode>). Uvedené se nevztahuje na díla či prvky (např. obrazovou či fotografickou dokumentaci), které jsou v díle užity na základě smluvní licence nebo výjimky či omezení př́slušných práv.

\section{https://doi.org/10.5817/OS2020-1-10}

\section{Solidarita má minulost' aj budúcnost'}

POLLÁK, M. (ed.): Solidarita. Levoča: Krásny Spiš, 2019. 538 s. ISBN 978-80-89975-01-3.

Na vydanie publikácie či už jednotlivca, alebo tímu spoluautorov vždy jestvuje silný motív a rovnako výrazná udalost', skúsenost', poznanie či rozhodnutie oslovit spoločenstvo, sociálnu skupinu, názorových bližencov, no v prípade umeleckej spisby predovšetkým tých, ktorým sú blízke výnimočné príbehy.

Naše nové storočie sa vyhraňuje svojimi prežívajúcimi i novovznikajúcimi politickými, humanitárnymi, ekonomickými, vojenskými, klimatickými a dalšími problémami, ale aj všeličím a všelijako s realitou prostého života stále častejšie aj naliehavejšie ovládaného mediálnymi nástrojmi a nimi sprostredkovaný kontakt. Aj vdaka ich prítomnosti zostáva stále menej času na dialóg a stretnutia naplnené vymieňaním si poznatkov, postrehov i odporúčaní, ako by sa to, čo vyvoláva nepokoj, dalo, či bolo by možné účinne riešit.

Za taký počin treba považovat vydanie unikátnej, poučenej a odborne aj občiansky profilovej publikácie takmer siedmich desiatok tvorcov rozličných odborných špecializácií, generačne odlišného veku, nie raz nelahkými okolnostami utváranej či získanej životnej filozofie, odlišného vzdelania a jeho špecializácie, teda autormi sú jednotlivci od politológa, sociológa, ekonóma, právnika, architekta, výtvarníka, publicistu, teatrológa, literárneho vedca, matematika, kňazov až po etnografičku, prírodnú vedkyňu, divadelnú režisérku, učitelku a aktivistu zo slovenského, českého aj madarského spoločenského prostredia.

Autori svoje príspevky zasielali editorovi publikácie Solidarita (2019), občianskemu aktivistovi Miroslavovi Pollákovi, od 3. 10.2017 až do 14. 3. 2019. Dátum zaslania príspevku poskytol zostavovatelovi publikácie klúč na jej kompozíciu, teda na 